\title{
Film-Induced Tourism - Factors Affecting Vietnamese Intention to Visit Korea
}

\author{
Pham Hong Hoa, Vo Thi Thanh Truc, and Mai Ngoc Khuong
}

\begin{abstract}
This paper aimed to identify the determinants of Vietnamese intention to visit Korea after watching Korean TV dramas or movies. Quantitative method was mainly employed and a self-administered questionnaire survey was conducted with sample size of $\mathbf{3 8 0}$ Vietnamese respondents. The results showed that the more Korean film makers invested in the topics and contents; actors, music and backgrounds; culture and tradition; and humanism contents, the more likely Vietnamese tourists intend to travel to Korea. Factors of "perception changes on Korean country's image" and "frequency of watching Korean film" were also positively associated with the travel intention. In addition, the empirical results indicated that factors of film topics and contents; actors, music and backgrounds; culture and tradition were significantly affected the frequency of watching and perception change on country image, which implied that Korean film has globally differentiated itself with other nations' films industry by focusing into the unique aspects of its social cultural values.
\end{abstract}

Index Terms-Film-induced tourism, film-tourism, destination perception, Vietnam and Korean tourism.

\section{INTRODUCTION}

Globalization, nowadays, can lessen the distance between two or more countries about geography, economic and culture. So far, the most easily seen of cultural effects and dominance on not only Vietnamese nations but also other Asian countries is Korean wave or Korean popular culture or Hallyu (in Korean language).

Since 1990s, Korean popular culture, a regional phenol-menon, has impact on many countries in Asia from well-produced and inexpensive film series at the beginning to extremely touched music. Although Vietnam not only took many aspects similar to China as ethical and philosophical system developed by Confucius but was affected by Chinese occupation for thousand years as well. Korean wave, at the present age is more popular when "Winter Sonata" was on air on Vietnamese television for the first time. And up to now, Vietnamese audiences are very familiar with number of Korean dramas such as "Autumn Love Song", "Love story in Harvard", "Full house", "Boys over flowers", "Jewel in the Palace" and many other drama series.

According to Dang [1], traditional values contents, nice storylines, beautiful locations, talented actors and actresses are key factors that make the attractive of Korean dramas to be broadcast and re-broadcast in many Vietnam national and local channels. Besides, Korean films have illustrated for its successful achievement on increasing number of tourists and

\footnotetext{
Manuscript received November 4, 2013; revised January 7, 2014.

The authors are with the School of Business, International University -VNU-HCM, Vietnam (e-mail: phhoa@hcmiu.edu.vn, trucvothithanh@gmail.com, mnkhuong@hcmiu.edu.vn).
}

revenue in return from tourism industry [2]-[5].

While several previous research was conducted in developed nations such as Japan, China (mainland) and Hong Kong [2], [3], [6] in order to find out the influences of Korean popular culture (including films, Korean cuisine and "Hallyu" products) on nationals of those countries. None of the research has been undertaken to explore Korean pop culture penetration into the new emerging market like Vietnam where revealed the increase in outbound tourism by $20 \%$, bringing about USD3.5 billion oversea in 2012 [7]. Hence, the purpose of this study is to examine the impacts of the specific factors of Korean films and two intervening variables of "perception changes on Korean country's image" and "frequency of watching Korean films" on "intention to visit Korea" in the context of Vietnam. Furthermore, this research also contributes for the promotion of Korean tourism through its film industry by 1) clarifying specific features of Korean TV drama series or movies that Vietnamese audiences interested in, 2) determining which factors affect to positive change on perception about Korean country and frequent of watching films, and then 3 ) providing recommendations for harnessing Korean films for tourism industry.

\section{LITERATURE REVIEW}

\section{A. Film-Tourism}

Attracting tourists to film locations through TV drama series or movies as new type of tourist destination at the present age is raising consideration of not just tourism marketers but many researchers in both developed and developing counties as well. For example, studies carried out by [2], [3], [5], [6], [8]-[11].

Beeton [12] cited in [14], [15], movie induced tourism happens when the success of film stimulates tourists to travel to the place where film shot. Six years after the millennium, Hudson and Ritchie [16] also stated that the appearance or attraction of destination featured in cinema, video or television would generate film tourism. In addition, there are several factors that affect the success of film tourism in specific region [15]. However, this paper merely focuses on the impacts of film-specific factors of Korean TV drama series or movies on Vietnamese audiences about its nation's image and Vietnamese residents' intention to travel to film location after frequently watching Korean films.

\section{B. Film-Specific Factors}

In their article related to film-induced tourism, Halm andWang [17] cited [18] who pointed out that amazing landscape qualities, a unique social and cultural outlook, an icon, and/ or an image are all film features that awake tourists' 
curiosity to explore. Iwashita [10] also agreed that what appeals to audiences is physical properties (spectacular scenery or landscape) portrayed in popular culture as literature, themes, storylines, events and characters.

Hatcher [19] determined six key elements of drama, encompassing action or plot, characters, thoughts or ideas, verbal expressions, music, and spectacle. Riley, Baker and Van Doren [11] also fleshed out with some features bearing on film contents that appeals viewers like storyline theme, exciting sequences, and human relationships.

In order to reminiscent the viewers of their emotional feeling created by the story and characters of the film, the background music, visual enhancement, and celebrity icon are tailored so that it can touch viewers' hearts [4]. Hobson [20] provides a list of vital elements, which cannot be eliminated in terms of audience's view, including celebrity endorsement (actors, costume and make up), contents (cliffhangers at the ending of each discrete episode and topicality), locations or sets and music.

Subsequently, Kim et al., [21] emphasized that characters, a key element of production values, are as important as celerity endorsement. In general, Hobson [20] and Kim et al., [21] are proponents for celebrities' involvement in the drama since their characters' personalities and stories reflect audiences' real lives.

Base on consumption orientation, the list of seven factors proposed by [11] cited from [21] was categorized into four main factors which are contents (storyline themes, exciting sequences), celebrity endorsement (popular movie stars and characters), music (sound technology effects), and scene (visual effects and picture perfect settings).

To recapitulate, the writer of this study examine four dimensions of film-specific that have stimulated audiences to watch and change their view of Korea: (1) topics and contents [2], [3], [10], [11], [17], [20], (2) humanism contents [2], [3], [17], (3) celebrities, music and scene background [2], [4], [10], [11], [17], [19]-[21] (4) culture and tradition [2], [3], [17].

\section{Frequently of Watching and Positive Perception Change on Country's Image}

In the simplest way, destination image is defined as either impressions or perceptions of destination bearing in mind of tourists [22]-[24] cited from 10]. By combining several previous literature descriptions, Kim and Richardson [25] then came up with the definition of destination image as "a totality of impressions, beliefs, ideas, expectations, and feelings accumulated towards a place over time". Therefore, it is impossible to refuse that image is very important to shape potential tourists' perceptions and views about destination [26].

Besides, viewers invariably perceive or evaluate the obtained information from this source more objectively and impartially than traditional promotion campaigns [25], [26]. That is the reason why film is used as new type of promotion in order to attract audiences' attention by creating positive destination images as backdrops in film [18] since when an image of a place is introduced on television or silver screen, it can strengthen its position in viewers' mind or even nurture and evolve images of new ones [26]. Therefore, based on the above argument, this research will investigate whether four factors Korean films positively affect the changes in country's image in minds of Vietnamese nationals.

Compared with destination marketing, film and television are two visual media which have more powerful impact on number of tourists enduring in any specific periods of time [18]. Many other researchers also provided several empirical studies about the significant impact of popular film on destination image and the stimuli to visit filming locations [2], [3], [10], [11], [25], [27]-[29]. Therefore, in order to induce tourism by television drama series or movies, each of its features must create credible images and information time after time so that audiences are of interests to visit.

According to Iwashita, tourists will choose to visit a country due to their positive attitude toward knowledge of nation, nature, culture or society. He also claimed that an actual visit is probably the consequence of positive image of the nation. Iwashita also cited [30]'s reasoning about the important role of images as one of the motivations of many visitors. Likewise, Kim and Richardson [25] cited from [31] confirmed destination image, as one of the most significant role and a critical factor on tourism decision-making process, respectively. So, the intention to visit film locations depends not only on film itself but the friendliness of the place images after watching it time and time again.

Base on the above discussion, we came up with the hypotheses and research model as below. Four independent variables preferring Korean film in research of [3] were adapted for the situation of Vietnam. Besides, from the previous discussion, this research also examines the relationship between each feature of Korean films with changes in Vietnamese perception about Korean image and intention to travel to Korea. In addition, the result from a descriptive statistic test, the number of Vietnamese people frequently watched Korean TV drama series or movies accounted for a hefty plurality of $83.8 \%$. So, it is necessary to test which dimensions of Korean film has seduced Vietnamese audiences to watch gradually, and subsequently have more favorable image of Korea as well as intend to visit this nation.

H1: Frequency of watching Korean TV drama series or movies is positively associated and affected by factors of topics and contents; actors, music and backgrounds; culture and tradition; and humanism contents.

$\mathrm{H} 2$ : Perception change in the country image of Korea is positively affected by factors of topics and contents; actors, music and backgrounds; culture and tradition; and humanism contents.

H3: Intention to visit Korea is positively affected by factors of topics and contents; actors, music and backgrounds; culture and tradition; and humanism contents.

H4: Intention to visit Korea is positively affected by factors of frequency of watching Korean TV drama series or movies and perception change in the country image of Korea.

H5: Intention to visit Korea is indirectly affected by factors of topics and contents; actors, music and backgrounds; culture and tradition; and humanism contents through the frequency of watching Korean TV drama series or movies and the perception change in the country image of Korea. 


\section{Methodology}

Sample of this research included only Vietnamese residents who are frequently watch Korean TV drama movies or series. Quota sampling was employed to collect data with three different control characteristics of age, gender and income. More than 616 survey questionnaires were collected in both Ha Noi and Ho Chi Minh City; however, there were only 380 usable surveys for data analysis in next part. So the ratio of sample size $(\mathrm{N})$ to the number of variables being analyzed (p) is greater than 20:1. Besides, there were 18 items of reason for preferring Korean film, representing four distinct groups of variables as topics and contents; actor, music and scene background; culture and tradition; and humanism content.

\section{A. Questionnaire Design}

In order to design survey questionnaire, several journal articles related to travel and tourism marketing or film-tourism were reviewed; together with a half-hour group discussion with 12 Vietnamese nationals. Since this study was about Korean film, so it mainly based on two research of Kim et al. about the effects of Korean pop culture on Japanese tourists and Hong Kong residents in two consecutive years, 2007 and 2008 [2], [3]. Combined 17 items from these research and one more item from group discussion, it was 18 items being measured in 5-point Likert scale with 1 = strongly disagree, 2 = disagree, $3=$ neutral, $4=$ agree and $5=$ strongly agree. Furthermore, the survey questionnaire was written in both Vietnamese and English language and was tested by marketing lecturer at International University - Vietnam National University as well as group of Vietnamese respondents in order to have better amendments. Then, the first 180 drafts of questionnaire were delivered to assess internal consistency of the entire scale. After eliminating one items of "Korean dramas are not oriented to commercialism." Cronbach's alpha of all concepts were at acceptable limit of .60 in exploratory research [32 cited from 33]. Ultimately, main study was carried out by collecting data through full survey.

\section{B. Factor Analysis and Reliability}

By employing principle component extraction with varimax rotation approach, exploratory factor analysis (EFA) was used for only 17 items of independent variables related to reason for preferring Korean film. However, before running EFA, it was necessary to examine values of corrected item-total correlation, reliability coefficient and especially, measure of sampling adequacy (MSA) to ensure the appropriateness of factor analysis. All results after running SPSS shown that all item-total correlations, Cronbach's alpha coefficients and MSA of each item were greater than a limit of 0.30 [34], 0.60, and 0.50 [33], respectively. Next, factor analysis was applied for four exogenous constructs of independent variables. Kaiser-Meyer-Olkin (KMO) measure of sampling adequacy was 0.825 greater than the acceptable limit of 0.60 [35]. The significant result from Bartlett test of sphericity also $(p<0.001)$ demonstrated that there were some correlations among variables. Hence, similar to MSA, KMO and Bartlett's test proved the suitability of current data for factor analyses.

To know the number of significant factors to be extracted, eigenvalue with a cutoff at 1 was used for 17 items. Then, to guarantee the validity of each concept, only 16 items were remained with loadings greater than 0.40 for each [36]. In addition, the total amount of variance extracted was $57.82 \%$ and Cronbach's alpha ranged from 0.624 to .781 . It meant that the entire scale of measurement achieved the appropriateness of reliability (See Table I).

TABLE I: SUMMARY OF INDEPENDENT VARIABLES WITH RELIABILITY COEFFICIENTS

\begin{tabular}{lcc}
\hline Given Names & $\begin{array}{c}\text { Number of } \\
\text { Items }\end{array}$ & Alpha \\
\hline Factor 1 Topics and contents (TCK) & 5 & .779 \\
Factor 2 Actors, Music and backgrounds (AMK) & 4 & .727 \\
Factor 3 Culture and tradition (CTK) & 4 & .651 \\
Factor 4 Humanism contents (HCK) & 3 & .623 \\
\hline \hline
\end{tabular}

The dependent variables of this study included three single-item variables as summarized in Table II. These variables were measured by 5-point scale; variable of frequency of watching Korean film the scale ranging from 1 = never, 2 = mostly not, $3=$ seldom, $4=$ sometime, 5 = often; variable of perception change on image of Korea the scale ranging from $1=$ very unfavorable, $2=$ somewhat unfavorable, $3=$ the same, $4=$ somewhat favorable, $5=$ very favorable; and the intention to visit Korea the scale was ranging from $1=$ absolutely not intent to, $2=$ somewhat not intent to, 3 = neutral, $4=$ somewhat intent to, $5=$ absolutely intent to.

TABLE II: SUMMARY OF DEPENDENT VARIABLES

\begin{tabular}{lc}
\hline \hline Given Names & $\begin{array}{c}\text { Number of } \\
\text { Items }\end{array}$ \\
\hline Frequency of watching Korean films (FREWAKO) & 1 \\
Perception change on image of Korea (PERIMKO) & 1 \\
Intention to visit Korea (INTOVIKO) & 1 \\
\hline \hline
\end{tabular}

\section{RESUlTS}

\section{A. Profile of Respondents}

The Profile of Respondents in the study are shown in Table III.

\section{B. Factors Affecting the Intention to Travel to Korea}

Table IV shows the significance of positive relationships between dependent variable of "intention to visit Korea" and other independent variables of four aspects of Korean film and two intervening variables. It was not difficult to realize that the relationships between "intention to visit Korea" and "positive change in Korean country's image" ( $r=0.581$, $p<0.0005)$. Additionally, "frequently of watching Korean films" also remarkably related to "intention to visit Korea" $(r=0.566, p<0.0005)$. It means that when Vietnamese nationals have more positively changed their perception of 
Korean image and more frequently watched K-dramas, they will be more desire to travel to Korea. Besides, significantly, all four factors of Korean film had moderate correlation with "intention to visit Korea". So each of these noticeable features somewhat stimulates the increase in the number of Vietnamese tourists to Korea.

TABLE III: PROFILE OF RESPONDENTS $(N=380)$

\begin{tabular}{|c|c|c|c|}
\hline Variable & $N, \%$ & Variable & $N, \%$ \\
\hline Gender & & Marital status & \\
\hline Female & $192(50.5)$ & Single & $215(56.6)$ \\
\hline Male & $188(49.5)$ & Marriage & $165(43.4)$ \\
\hline Total & $380(100)$ & Total & $380(100)$ \\
\hline Age & & Educational qualification & \\
\hline $10-19$ & $87(22.9)$ & Secondary high school & $10(2.6)$ \\
\hline $20-29$ & 113 (29.7) & High school & 44 (11.6) \\
\hline $30-39$ & $61(16.1)$ & College/ University & $121(31.8)$ \\
\hline $40-49$ & $70(18.4)$ & University graduates & $166(43.7)$ \\
\hline 50 or above & 49 (12.9) & Post graduate & $39(10.3)$ \\
\hline Total & $380(100)$ & Total & $380(100)$ \\
\hline Occupation & & Monthly income (VND) & \\
\hline Officials & $93(28.3)$ & Less than $1,499,999$ & $93(24.5)$ \\
\hline Teacher/ Lecturer & $14(3.7)$ & $1,500,000-2,999,999$ & $22(5.8)$ \\
\hline Students & $127(33.4)$ & $3,000,000-4,499,999$ & $58(15.3)$ \\
\hline Company employee & $80(21.1)$ & $4,500,000-7,499,999$ & $110(28.9)$ \\
\hline Businessman & $12(3.2)$ & $7,500,000$ - 14,999,999 & 75 (19.7) \\
\hline Housewife & $9(2.4)$ & $15,000,000$ or above & $22(5.8)$ \\
\hline Professional & $9(2.4)$ & Total & $380(100)$ \\
\hline Others & $21(5.5)$ & & \\
\hline Total & $380(100)$ & & \\
\hline
\end{tabular}

\section{Indirect Effects of the Intention to Travel to Korea}

\section{1) Frequently of watching Korean film}

Result from multiple regression analysis shown that "frequently of watching Korean film" had two significant predictors, "topics and contents" of films $(\beta=0.429, p<0.05)$ and Korean "actors, music and scene backgrounds" $(\beta=0.119$, $p<0.05)$. Therefore, only two out of four factors of Korean film directly affected to "the frequency of watching", and then "the frequency of watching" caused the direct effect upon the "intention to visit Korea" $(\beta=0.332, p<0.05)$. Moreover, through the intervening variable of "frequency of watching Korean film", the two factors of "topics and contents" and "actors, music and scene backgrounds" created the indirect impacts on "intention to visit" at (0.142) and (0.040), respectively. So, in this case, both "topics and contents" and "actors, music and scene backgrounds" positively affected "frequently of watching" and "intention to travel to Korea". Thus, this study has been proved that the better "topics and contents" and "actors, music and scene backgrounds", the more people watch K-dramas and are also intent to visit film-location later on.

Path Diagram of the Direct and Indirect Effects of Intention to Visit Korea.

TABLE IV: DESCRIPTIONS AND VARIABLES' CORRELATIONS OF THE INTENTION TO VISIT KOREA MODEL

\begin{tabular}{|c|c|c|c|c|c|c|}
\hline & INTOVIKO & 1 & 2 & 3 & 4 & 5 \\
\hline 1. TCK & $0.357 * *$ & & & & & \\
\hline 2. AMK & $0.325 * *$ & $0.243 * *$ & & & & \\
\hline 3. CTK & $0.260 * *$ & $0.396 * *$ & $0.319 * *$ & & & \\
\hline 4. HCK & $0.237 * *$ & $0.460 * *$ & $0.271 * *$ & $0.411 * *$ & & \\
\hline 5. FREWAKO & $0.566^{* *}$ & $0.456^{* *}$ & $0.224 * *$ & $0.224 * *$ & $0.212 * *$ & \\
\hline 6. PERIMKO & $0.581 * *$ & $0.390 * *$ & $0.330 * *$ & $0.299 * *$ & $0.240 * *$ & $0.632 * *$ \\
\hline Mean & 4.1 & 17.8 & 16.3 & 14.3 & 11.1 & 4.2 \\
\hline SD. & 0.8 & 3.5 & 2.5 & 2.3 & 1.9 & 0.8 \\
\hline
\end{tabular}

Note: * Significant level at $p<0.0005$

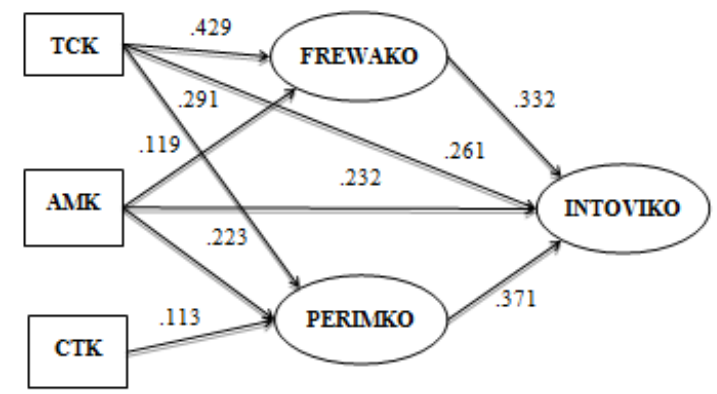

* Note: All coefficients in the model are significant at the 0.05 level.

Fig. 1. Path coefficients of the structural equation for hypothesis testing.

\section{2) Perception change on country image of Korea}

From the result of multiple regression analysis, three significant variables contributed for "perception change on Korean country's image" were "topics and contents" $(\beta=0.291, p<0.05)$, "actors, music and scene backgrounds" $(\beta=0.223, \quad p<0.05)$ and Korean "tradition and culture" $(\beta=0.113, \quad p<0.05)$. Then "perception change" directly affected the "intention to visit Korea" $(\beta=0.371, p<0.05)$. Thus, through intervening variable of "perception change on Korean country's image", these three factors indirectly affected "intention to travel to Korea" at (0.108), (0.083) and (0.042). These findings indicated that three factors of reason for preferring Korean film positively related to "perception change on Korean country's image" and "intention to travel to Korea". It means that audiences are more favorable with Korea and its tourism when they perceive the increase in attractiveness of K-dramas, actors and Korean unique traditional and cultural value.

\section{Direct Effects of the Intention to Travel to Korea}

In order to explore the direct effects of the independent and 
intervening variables on "intention to visit to Korea", the results from multiple regression analyses shown that "intention to visit Korea" had four significant contributors "topics and contents $(0.429, p<0.05)$, "actors, music and scene backgrounds" $(0.232, p<0.05)$, positive change in country's image $(0.371, p<0.05)$ and "frequently of watching K-drama" $(0.332, p<0.05)$.

\section{E. Total Casual Effects of the Intention to Travel to Korea}

The total effects of four factors of Korean film along with "frequently of watching" and "perception change on country's image" on dependent variable of "intention to travel to Korea" was shown in Table V. Base on column of the total effects, "topics and contents" of Korean films had strongest effect on "intention to visit Korea" with $\beta=0.511$, followed by "perception change on Korean country's image" with $\beta=0.371$. Being classified as moderate to low effects, "actors, music and scene backgrounds", "frequently of watching" and Korean "culture and tradition" had beta equal to $0.354,0.332$ and 0.042 , respectively. The total of effect of these factors on "intention to visit Korea" is 1.610 .

TABLE V: DIRECT, INDIRECT, AND TOTAL CAUSAL EFFECTS

\begin{tabular}{lccc}
\hline \hline \multirow{2}{*}{$\begin{array}{c}\text { Independent } \\
\text { Variables }\end{array}$} & \multicolumn{3}{c}{ Causal effects } \\
\cline { 2 - 4 } TCK & Direct & Indirect & Total \\
AMK & 0.261 & 0.250 & 0.511 \\
CTK & 0.232 & 0.122 & 0.354 \\
FREWAKO & ---- & 0.042 & 0.042 \\
PERIMKO & 0.332 & ---- & 0.332 \\
& 0.371 & ---- & 0.371 \\
& 1.196 & 0.414 & 1.610 \\
\hline \hline
\end{tabular}

Regard to direct effect, "intention to visit Korea" received the strongest impact from "perception change on country's image" with $\beta=0.371$, followed by another intervening variable of "frequently of watching" $(\beta=0.332)$. The last two effects were belong to "topics and contents" $(\beta=0.261)$ and "actors, music and scene backgrounds" $(\beta=0.232)$.

Lastly, "topics and contents" indirectly caused the most noticeable effects on the direct variable at $\beta=0.250$. Then, the other two factors of Korean films being ranked in the last two effects on "intention to visit Korea" were "actors, music and scene backgrounds" $(\beta=0.122)$ and Korean "culture and tradition" $(\beta=0.042)$.

\section{DisCUSSION AND CONCLUSION}

This empirical study conclusively prove that factors of Korean film directly and indirectly affect the flow of Vietnamese tourists to Korea along with providing reliable scale of measurement of each concepts. This study also measured the dependent variable of intention to visit Korea through intervening variables, frequency of watching Korean film and perception change on Korean image.

One of the most important reasons affected to frequency of watching, positive perception change and intention to travel to Korea is "topics and contents" of Korean films. Since, Korean film has differentiated itself with other films industry by reflecting everyday life and society, instead of containing too much violence like many other western countries or mainly focusing on martial art.

Followed "topics and contents", factor of "actors, music and scene backgrounds" also leaded to an increase in the number of audiences watching Korean film, making a very favorable impression on Korean image and subsequently intending to travel to Korea. In fact, Korean film industry carefully invested in attractive celebrities, beautiful soundtrack and dramatic backdrop since people choose to visit film location because of not only beautiful scenery but the feelings they used to experience during the film.

Although Korean "culture and tradition received minority interested from Vietnamese audience. However, it is also one potential feature to develop in order to 1) diversify many types of Korean films, 2) promote unique and homogenous culture of Korea, and 3) change the perception of audiences about Korea in positive way, not just including wars and territorial disputes.

The "intention to visit Korea" received higher impact from "perception change" rather than "frequency of watching". It means that the noticeable number of Korean films being aired on Vietnam national and local channels is less important than the positive change on audiences' perception. Hence, the quality of Korean decides how Vietnamese nationals perceive Korean image and intent to visit Korea. For that reason, to increase audience loyalty to Korean films, Korean film-makers should invest more on its quality instead of quantity.

One of the limitations of this research is that it was conducted mainly in Ho Chi Minh City with a small proportion of survey questionnaires collected from Ha Noi. So next researchers should deliver and collect survey from various places, especially three regions of Vietnam so as to ensure the generalizability of the result. Beside the contribution of this study for Korean film production, further research should address the role of government and tourism agencies in order to promote destination images [16]. Furthermore, it is necessary to investigate what particular type of tour or tour packages that Vietnamese audiences actually want to participate in. Additionally, together with film, there are other aspects of Korean popular culture such as music, 'Hallyu products' and Korean cuisine which are probably endorse in film to exploit the consequences from film-induced tourism.

\section{REFERENCES}

[1] D. T. T. Huong. (June, 2009). Hallyu and its effect on young Vietnamese. [Online]. Available: http://www.vanhoahoc.vn/nghien-cuu/tai-lieu-tieng-nuoc-ngoai/vietna mese-culture/1319-dang-thi-thanh-huong-hallyu-and-its-effect-on-you ng-vietnamese.html

[2] K. S. Samuel, A. Jerome, L. Heesung, and C. Kaye, "Effects of Korean television dramas on the flow of Japanese tourists," Tourism Management, vol. 28, no. 5, pp. 1340-1353, October 2007.

[3] K. S. Samuel, A. Jerome, C. Kaye, and C. Youngshin, "The effects of Korean pop culture on Hong Kong residents' perceptions of Korea as a potential tourist destination," Journal of Travel and Tourism Marketing, vol. 24, no. 2-3, pp. 163-183, 2008.

[4] K. Sangkyun, "Extraordinary experience: Re-enacting and photographing at screen tourism locations," Tourism and Hospitality Planning and Development, vol. 7, no. 1, pp. 59-75, March 2010. 
[5] K. Sangkyun and W. Hua, "From television to the film set: Korean drama Deajanggeum drives Chinese, Taiwanese, Japanese and Thai audiences to screen-tourism," International Communication Gazette, vol. 74, no. 5, pp. 423-442, August 2012.

[6] K. Seongseop, K. Miju, A. Jerome, and L. Aejoo, "Does a food-themed TV drama affect perceptions of national image and intention to visit a country? An empirical study of Korea TV drama," Journal of Travel and Tourism Marketing, vol. 29, no. 4, pp. 313-326, 2012.

[7] N. T. Tam. (Jan. 2013). Du khách Việt Nam mang USD 3, 5 tỉ ra nước ngoài. [Online]. Available: http://www.thanhnien.com.vn/pages/20130129/du-khach-viet-mang-3 -5-ti-usd-ra-nuoc-ngoai.aspx

[8] C. Joanne, "Toddlers, tourism and Tobermory: Destination marketing issues and television-induced tourism," Tourism Management, vol. 26 , pp. 763-776, October 2005.

[9] C. Joanne, "Film tourism-Evolution, progress and prospects," Tourism Management, vol. 33, no. 5, pp. 1007-1029, October 2012

[10] I. Chieko, "Media representation of the UK as a destination for Japanese tourists: Popular culture and tourism," Tourist Studies, vol. 6, no. 1, pp. 59-77, April 2006.

[11] R. W. Roger, B. Dwayne, and D. C. S. Van, "Movie induced tourism," Annual of Tourism Research, vol. 25, no. 4, pp. 919-935, October 1998.

[12] B. Sue, Film-Induced Tourism, Channel View Publications, Clevedon, 2005.

[13] B. Sue, "Location, location, location: Film's Corporations' Social Responsibilities," Journal of Travel \& Tourism Marketing, vol. 24, no. 2/3, pp. 107-114, 2008.

[14] S. H. Jen, H. A. Yu, B. Glen, and K. H. Jeong, "The impact of product placement on TV-induced tourism: Korean TV dramas and Taiwanese viewers," Tourism Management, vol. 32, no. 4, pp. 805-814, August 2011.

[15] C. J. Y and Y. S. Shuo, "The examination of factors influencing residents perceptions and attitudes toward film induced tourism," African Journal of Business Management vol. 5, no. 13, pp. 5371-5377, July 2011.

[16] H. Simon and R. J. R. Brent, "Promoting destinations via film tourism: An empirical Identification of supporting marketing initiatives,' Journal of Travel Research, vol. 44, pp. 387-396, May 2006.

[17] R. W. Roger and D. C. S. Van, "Movies as tourism promotion. A "pull factor" in a "push location," Tourism Management, vol. 13, no. 3, pp. 267-274, Septemper1992.

[18] H. Jeeyeon and W. Youcheng, "Film-induced tourism as a vehicle for destination marketing: Is it worth the efforts?" Journal of Travel and Tourism Marketing, vol. 28, no. 2, pp. 165-179, Feb. 2011.

[19] J. Hatcher, The Art and Craft of Playwriting, Cincinnati, OH: Storey Press, 1996.

[20] H. Dorothy, Soap Opera, Cambridge: Polity Press, 2003.

[21] K. Sangkyun, R. Mike, and P. Long, "Understanding popular media production and potential tourist consumption: A methodological agenda," in Proc. the 2006 International Tourism and Media Conf., 2006, pp. 79-92.

[22] H. D. John, "Image as a factor in Tourism Development," Journal of Travel Research, vol. 13, no. 3, pp. 1-7, Jan. 1975.

[23] P. Angela, "Holiday destination image-The problem of assessment: An example developed in Menorca," Tourism Management, vol. 7, no. 3, pp. 168-80, Sep. 1986.

[24] G. C. William and H. D. John, "An analysis of state image change over a twelve-year period (1971-1983)," Journal of Travel Research, vol. 26, no. 2, pp. 15-19, October 1987.

[25] K. Hyounggon and R. L. Sarah, "Motion picture impacts on destination images," Annals of Tourism Research, vol. 30, no. 1, pp. 216-237, Jan. 2003.

[26] B. Peter and W. Lindsay, "The role of image in service promotion: focusing on the influence of film on consumer choice within tourism," International Journal of Consumer Studies, vol. 32, no. 4, pp. 382-390, July 2008

[27] B. Sue, "Rural tourism in Australia - has the gaze altered? Tracking Rural images through film and tourism promotion," International
Journal of Tourism Research, vol. 6, no. 3, pp. 125-135, May/June 2004.

[28] L. Christina, "Have magic, will travel': tourism and Harry Porter's United (Magical) Kingdom,” Tourist Studies, vol. 12, no. 1, pp. 52-69, April 2012.

[29] P. Steve, "The role of TV commercial visuals in forming memorable and impressive destination images," Journal of Travel Research, vol. 50, no. 2, pp. 171-185, March 2011.

[30] S. Subhash, S. A. Terence, and S. Jeongshin, "Consumer Ethnocentrism: a test of antecedents and moderators," Journal of the Academy of Marketing Science, vol. 23, no. 1, pp. 26-37, Dec. 1994.

[31] J. H. Olivia, "Understanding and measuring tourist destination images," International Journal of Tourism Research, vol. 1, no. 1, pp. 1-15, Jan/Feb. 1999.

[32] R. P. John, S. R. Phillip, and W. S. Lawrence, "Criteria for scale selection and evaluation," in Proc. the Measures of Personality and Social Psychological Attitudes, CA: Academic Press, 1991, ch. 1, pp. $1-16$.

[33] H. F. Joseph, B. C. William, B. J. Barry, A. E. Rolph, and T. L. Ronald, Multivariate Data Analysis (Sixth Edition), Prentice Hall. 2005.

[34] N. C. Jum and B. Ira, Psychometric Theory (Second Edition), New York: McGRAW-HILL Inc., 1994.

[35] K. F. Henry, "An index of factorial simplicity," Psychometrica, vol. 39, pp. 31-36, 1974

[36] G. W. David and A. C. James, "Structural equation modeling in practice: a review and recommended two-step approach," Psychological Bulletin, vol. 103, no. 3, pp. 411-423, 1988.

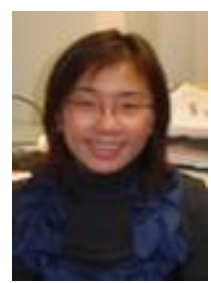

Pham Hong Hoa is a lecturer and the head of Marketing and Management Department, School of Business, International University - VNU-HCM, Vietnam. She has Doctor Degree in Business Administration (DBA), Victoria University, Melbourne, Australia 2012; Master of Business Administration (MBA), RMIT University, Melbourne, Australia 2004; and Master of Marketing (MMktg), Central Queensland University, Melbourne, Australia 2002. Her research interests include global marketing strategy at multinational corporations (MNCs), headquarters-subsidiary relationship, and international business issues in emerging market economies. In addition, she is now a professional member of American of Marketing Association (AMA), Australian New Zealand Academy of Management (ANZAM).

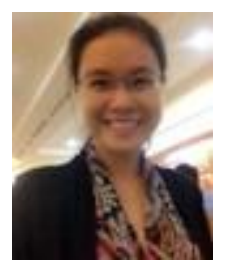

Vo Thi Thanh Truc is a research assistant of Marketing Department, School of Business Administration, International University, Vietnam National University, Ho Chi Minh.

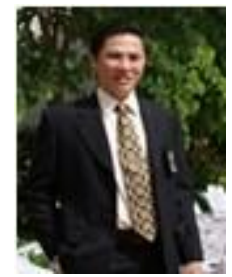

Mai Ngoc Khuong is a lecturer and researcher of School of Business Administration - International University, VNU-HCM. He has bachelor degree in Tourism and Hospitality Management, Master of Science degree in Leisure, Tourism and Environment at Wageningen University, The Netherlands, and $\mathrm{PhD}$ degree in Development Management at School of Public Administration of the National Institute of Development Administration (NIDA), Bangkok, Thailand. 